\title{
Absorption of antibiotics during peritoneal dialysis in patients with renal failure
}

\author{
A. C. BUCK ${ }^{1}$ and SIMON L. COHEN \\ From St. Mary's Hospital Medical School, London
}

SYNOPSIS Cloxacillin, ampicillin, cephaloridine, kanamycin, and polymyxin B were administeredo singly in the dialysis fluid of patients having peritoneal dialysis for chronic renal failure. Thera- peutic blood levels could be attained with all the drugs by the end of 12 hours of dialysis, using.a concentration in the dialysis fluid which did not produce any local toxic symptoms. Absorption $\infty$ rates across the peritoneum were higher for cephaloridine, ampicillin, and cloxacillin than for을 kanamycin and polymyxin $B$.

The serum half-lives after termination of dialysis were in excess of 11 hours, except that for cloxacillin which had a half life of about $2 \cdot 5$ hours.

Peritoneal dialysis is now used extensively for the treatment of acute renal failure and the maintenance of patients with chronic renal failure (Maxwell, Rockney, Kleeman, and Twiss, 1959; Thomson, Buchanan, Doak, and Peart, 1964; Palmer, Newell, Gray, and Quinton, 1966). The technique is relatively simple and does not require expensive apparatus but does suffer from the disadvantage that many patients contract peritoneal infections during treatment, especially where this is prolonged for several weeks or months. These infections can be treated either orally and intramuscularly or locally, by the addition of antibiotics to the dialysis fluid. In surgical peritonitis intraperitoneal administration appears to be the more effective method, but the high concentrations of antibiotics often used can be harmful (Cohn and Cotlar, 1962; Cohn, 1962).

Intraperitoneal antibiotics are absorbed to an extent sufficient to give appreciable serum levels in patients with renal failure. Tetracycline, chloramphenicol, kanamycin, and colistimethate reach blood levels between $2.5 \mu \mathrm{g} . / \mathrm{ml}$. and $12 \mu \mathrm{g} . / \mathrm{ml}$. when given in dialysis fluid in concentrations between $300 \mu \mathrm{g} . / \mathrm{ml}$. and $1,000 \mu \mathrm{g} . / \mathrm{ml}$. and allowed to remain in the peritoneal cavity for one hour (Greenberg and Sanford, 1967). Lower concentrations of ampicillin, cephalothin, tetracycline, and chloramphenicol give similar blood levels, when given over a much longer period by intermittent dialysis (Bulger, Bennett, and Boen, 1965; Rose, Roth, and Koch, 1965; Ruedy, 1966).

${ }^{1}$ Now at St. Bartholomew's Hospital, London.

Received for publication 1 May 1967.
The present work extends the study of the absorption of low concentrations of intraperitoneal antibiotics to cloxacillin, cephaloridine, kanamycin, and polymyxin $B$.

\section{PATIENTS AND METHODS}

The absorption studies were performed on adult pa-윽 tients awaiting renal transplantation (Mowbray, Cohen, Doak, Kenyon, Owen, Percival, Porter, and Peart, 1965). None of these patients had a creatinine clearance in excess of $2 \mathrm{ml}$. per minute; they were maintained in reasonable health by nightly peritoneal dialysis. At the time of the study some of the patients had intraperi- 3 . toneal infections, while in others the dialysate wasio sterile. None of the patients had as yet undergone any major abdominal surgery but most of them had suffered from one or more past episodes of peritoneal infection.

The antibiotics investigated were those that had been $>$ found empirically to be of most use in treating infections in these patients and included cloxacillin, ampicillin, cephaloridine, kanamycin, and polymyxin $B$. The con- $O$ centrations of each antibiotic in the dialysis inflow fluidn represented a compromise between the need for highN bactericidal activity while avoiding local or systemic ${ }_{\sigma}^{\omega}$ toxic effects. Thus cloxacillin, ampicillin, and cephalo? ridine could be given at concentrations around $50 \mu \mathrm{g} . / \mathrm{ml}$ while the concentrations of kanamycin and polymyxin品 B were limited to around $20 \mu \mathrm{g} . / \mathrm{ml}$. and $15 \mu \mathrm{g} . / \mathrm{ml} . ?$ respectively.

Each period of overnight dialysis consisted of seveno or eight consecutive two-hour exchanges during each of which 2 litres of antibiotic-containing fluid were run $\vec{D}$ into the abdomen over 15 minutes, retained for 450 minutes, and then allowed to drain during the following 
hour. Samples were taken from the dialysis fluid during inflow and outflow periods of each cycle and serum samples were obtained before, during, and after dialysis. Any urine passed during the 24 hours following the start of dialysis was also saved. These specimens were kept frozen at $-20^{\circ} \mathrm{C}$. for up to a week before being analysed altogether. Antibiotic assays were based on the methods described by Grove and Randall (1955). Five sets of standards and specimens were placed in Heatly cups on $14 \mathrm{~cm}$. nutrient agar plates seeded with an indicator organism. All the antibiotics except polymyxin B were left to diffuse for four hours at room temperature before incubation at $37^{\circ} \mathrm{C}$. for 24 hours. Polymyxin B, because of its slow rate of diffusion, was left overnight at $4^{\circ} \mathrm{C}$. before incubation. Sarcina lutea N.C.T.C. 8340, selected for resistance to kanamycin and polymyxin B, was used for estimating cloxacillin, ampicillin, and cephaloridine; it would detect serum levels of $0.5 \mu \mathrm{g} . / \mathrm{ml}$., $0.012 \mu \mathrm{g} . / \mathrm{ml}$., and $0.12 \mu \mathrm{g}$. $/ \mathrm{ml}$. respectively. Polymyxin B was assayed using Bordetella bronchiseptica N.C.T.C. 8344, which was resistant to the other antibiotics used and would detect levels of polymyxin down to $0.5 \mu \mathrm{g} . / \mathrm{ml}$. Kanamycin could also be detected down to this level using a strain of Bacillus cereus resistant to the other antibiotics.

Serum standards were made up in the patient's own serum taken before the start of the dialysis, while dialysis and urine standards were made up in phosphate buffer containing $0.25 \%$ bovine serum albumin. The latter solution was used for diluting dialysis fluid and urine samples.

The assay of polymyxin in the dialysis outflow fluid was complicated by the presence of a naturally occurring heat-stable inhibitor of the indicator organism. The outflow level given in Table $I$ is therefore a maximal value, while the calculated absorption rates are minimal values.

In order to compare the rate of absorption across the peritoneum of the different antibiotics an arbitrary standardized rate was calculated as follows: $R=\frac{A}{B \times C}$
$R$ is the arbitrary standardized rate

$A$ is the mean amount of antibiotic absorbed from the dialysis fluid of each patient, measured in $\mathrm{mg} . / 2$ litres

B is the antibiotic gradient across the peritoneum obtained by subtracting from the mean antibiotic concentration in the inflow dialysis fluid the mean serum concentration for the whole period of dialysis, both measured in $\mu \mathrm{g} . / \mathrm{ml}$.

$\mathrm{C}$ is the external surface area of the patient in square metres.

The serum half life of each antibiotic was determined from the fall of the blood level during the seven hours between periods of dialysis.

\section{RESULTS}

The concentrations of the five antibiotics administered in the inflowing dialysis fluid are shown in the Table; they ranged from $16.5 \mu \mathrm{g} . / \mathrm{ml}$. for polymyxin B up to $55 \mu \mathrm{g}$. $/ \mathrm{ml}$. for cloxacillin. These levels had been found empirically to be useful in treating peritonitis in patients with renal failure, without producing any toxic symptoms.

The concentrations of the antibiotics still present in the outflow dialysis fluid varied between 11.5 $\mu \mathrm{g} . / \mathrm{ml}$. for kanamycin up to $18.5 \mu \mathrm{g} . / \mathrm{ml}$. for cloxacillin. The observed fall in the concentrations is due partly to a dilution effect, as the volume of outflow dialysis fluid was normally greater than the inflow volume. The rest of the fall is due to absorption across the peritoneum; preliminary experiments had excluded the possibility of destruction of these five antibiotics in dialysis fluid.

The standardized absorption rates for the antibiotics show that cephaloridine, ampicillin, and cloxacillin were absorbed faster than kanamycin and polymyxin B. Individual patients within the five groups did not appear to have differences in absorption rates attributable to the presence or absence of

TABLE

\begin{tabular}{|c|c|c|c|c|c|c|c|c|c|}
\hline \multirow{3}{*}{ Antibiotic } & \multirow{3}{*}{$\begin{array}{l}\text { No. of } \\
\text { Patients }\end{array}$} & & & & & & & & \\
\hline & & \multirow[t]{2}{*}{$\begin{array}{l}\text { No. of } \\
\text { Assays }\end{array}$} & \multicolumn{2}{|c|}{$\begin{array}{l}\text { Mean Dialysis } \\
\text { Antibiotic Level } \\
(\mu g . / m l .)\end{array}$} & \multirow{2}{*}{$\begin{array}{l}\text { Mean } \\
\text { Absorption of } \\
\text { Antibiotic } \\
\text { from } 2 \text { l. of } \\
\text { Dialysis Fluid } \\
\text { in Milligrams }\end{array}$} & \multirow[t]{2}{*}{$\begin{array}{l}\text { Standardi- } \\
\text { zed Absorp- } \\
\text { tion Rate }\end{array}$} & \multirow{2}{*}{$\begin{array}{l}\text { Serum } \\
\text { Level } \\
\text { after 12-hr. } \\
\text { Dialysis } \\
\text { ( } \mu \mathrm{g} . / \mathrm{ml} .) \\
\end{array}$} & \multirow{2}{*}{$\begin{array}{l}\text { 12-hour } \\
\text { Serum } \\
\text { Levelas } \\
\text { Percentage } \\
\text { of Dialysis } \\
\text { Inflow } \\
\text { Level }\end{array}$} & \multirow{2}{*}{$\begin{array}{l}\text { Half-life } \\
\text { of Anti- } \\
\text { biotic in } \\
\text { Serum after } \\
\text { Dialysis in } \\
\text { Hours }\end{array}$} \\
\hline & & & Inflow & Outflow & & & & & \\
\hline Cloxacillin & 4 & 5 & $\begin{array}{l}55 \cdot 0 \\
(3 \cdot 77)^{1}\end{array}$ & $\begin{array}{l}18 \cdot 5 \\
(1 \cdot 07)\end{array}$ & $\begin{array}{l}67 \cdot 2 \\
(8 \cdot 06)\end{array}$ & 0.84 & $\begin{array}{l}4 \cdot 1 \\
(0 \cdot 96)\end{array}$ & $7 \cdot 5$ & $\begin{array}{l}2 \cdot 5 \\
(0 \cdot 30)\end{array}$ \\
\hline Ampicillin & 3 & 4 & $\begin{array}{l}38.8 \\
(0.59)\end{array}$ & $\begin{array}{l}14 \cdot 7 \\
(1 \cdot 14)\end{array}$ & $\begin{array}{l}41 \cdot 8 \\
(3 \cdot 13)\end{array}$ & 0.74 & $\begin{array}{c}7 \cdot 4 \\
(1 \cdot 24)\end{array}$ & $19 \cdot 0$ & $\begin{array}{l}11.8 \\
(0.43)\end{array}$ \\
\hline Cephaloridine & 5 & 6 & $\begin{array}{l}48 \cdot 0 \\
(4 \cdot 52)\end{array}$ & $\begin{array}{l}18 \cdot 2 \\
(1.48)\end{array}$ & $\begin{array}{l}55 \cdot 1 \\
(8 \cdot 37)\end{array}$ & 0.90 & $\begin{array}{l}11 \cdot 5 \\
(1 \cdot 56)\end{array}$ & $24 \cdot 0$ & $\begin{array}{l}14 \cdot 1 \\
(3 \cdot 62)\end{array}$ \\
\hline Kanamycin & 5 & 5 & $\begin{array}{l}20 \cdot 7 \\
(1 \cdot 29)\end{array}$ & $\begin{array}{l}11 \cdot 5 \\
(1 \cdot 27)\end{array}$ & $\begin{array}{l}14 \cdot 5 \\
(4 \cdot 12)\end{array}$ & 0.52 & $\begin{array}{c}5.6 \\
(0.71)\end{array}$ & $27 \cdot 0$ & $\begin{array}{l}35 \cdot 5 \\
(3 \cdot 54)\end{array}$ \\
\hline Polymyxin $\mathrm{B}^{2}$ & 5 & 5 & $\begin{array}{l}16 \cdot 5 \\
(0 \cdot 80)\end{array}$ & $\begin{array}{l}11.8 \\
(1.50)\end{array}$ & $\begin{array}{c}6 \cdot 4 \\
(2 \cdot 74)\end{array}$ & 0.30 & $\begin{array}{c}2 \cdot 6 \\
(0 \cdot 39)\end{array}$ & $16 \cdot 0$ & $\begin{array}{l}14 \cdot 3 \\
(3 \cdot 80)\end{array}$ \\
\hline
\end{tabular}

${ }^{1}$ The standard error of each mean is given in brackets.

${ }^{2}$ The polymyxin B content of dialysis outflow fluid is a maximum value while the figures given for the mean and standardized absorption rates are minimum values. For further details see the section on methods. 


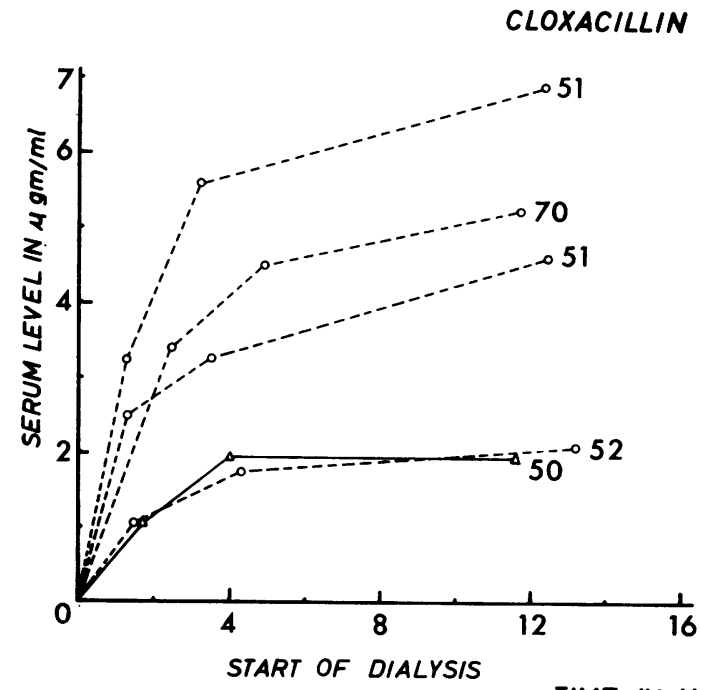

FIGS. 1-5. These show the rates of rise of antibiotic in the serum of patients during dialysis and the rates of fall after termination of dialysis.

The curves obtained from patients without peritonitis are shown as continuous lines, while those from patients with peritonitis are shown as broken lines.

The mean antibiotic concentration in the dialysis inflow fluid, in $\mu \mathrm{g} . / \mathrm{ml}$., is shown for each patient at the side of the corresponding curve.

TIME IN HOURS

AMPICILLIN

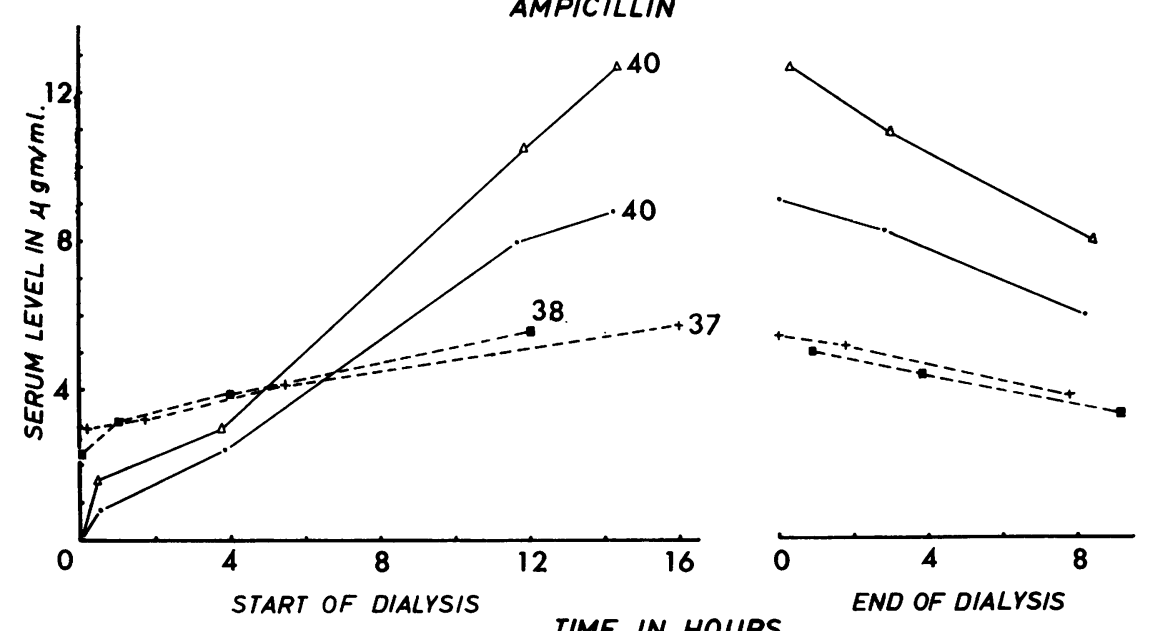

TIME IN HOURS

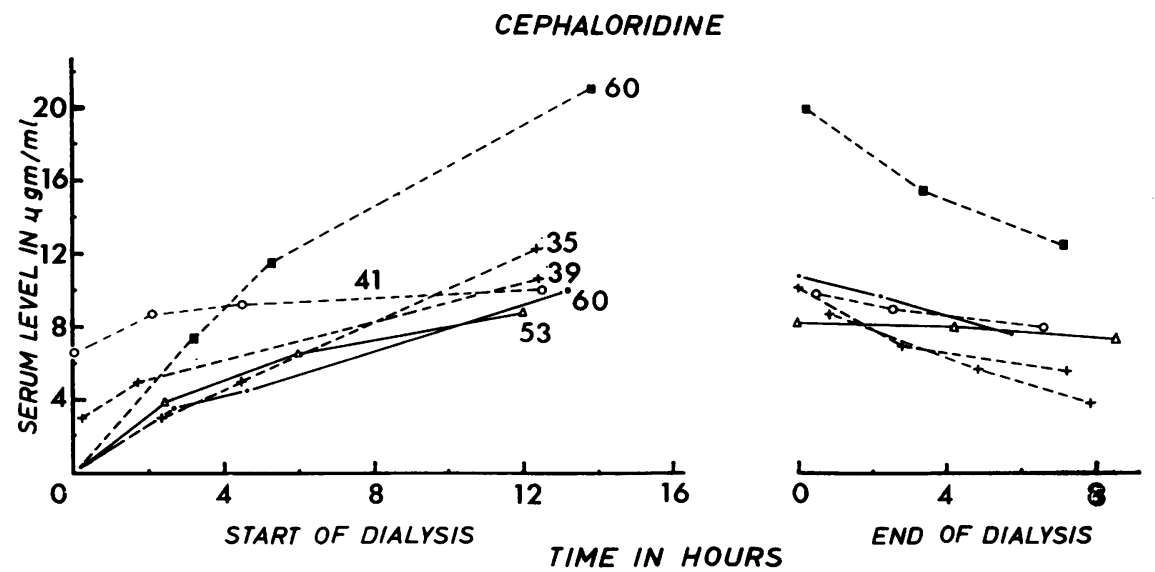


KANAMYCIN

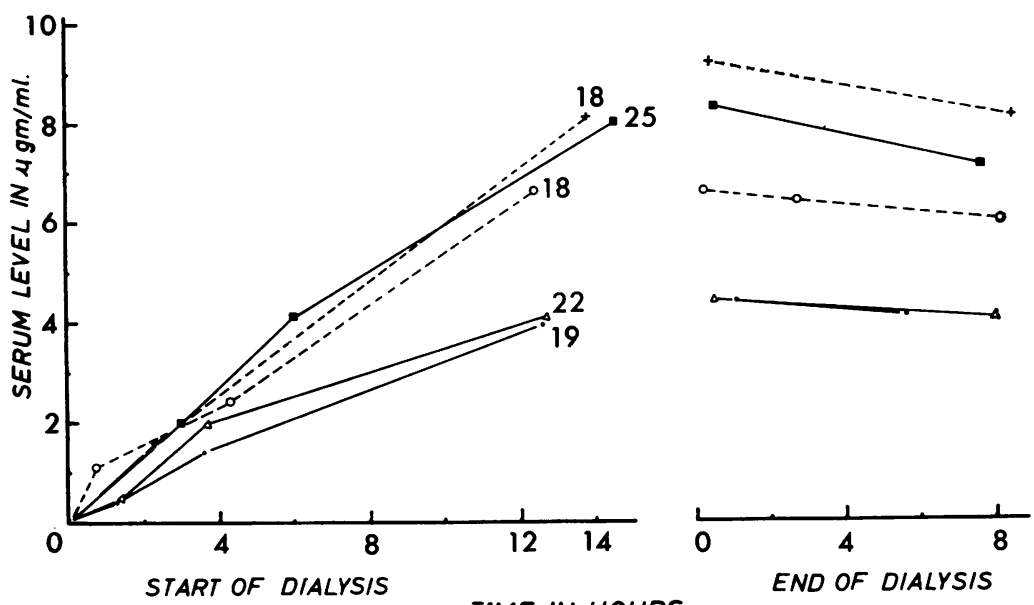

TIME IN HOURS

\section{POLYMYXIN B}

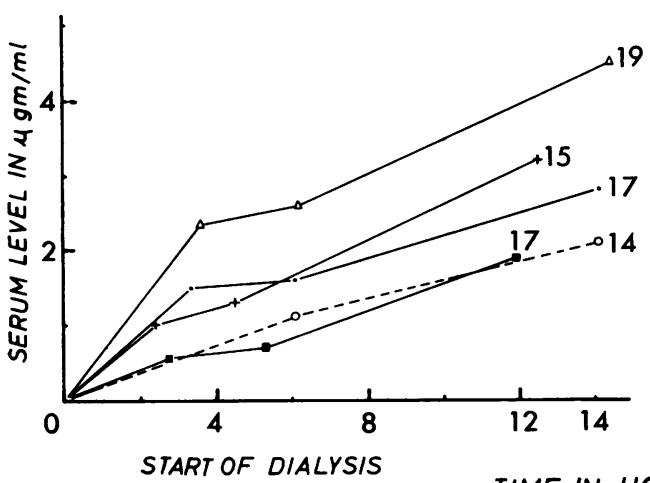

TIME IN HOURS

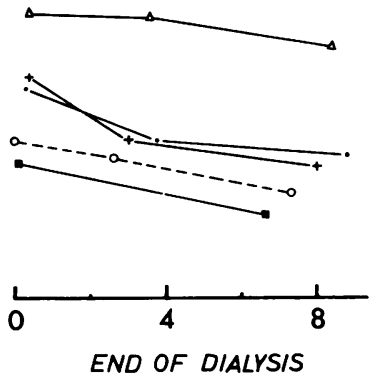

peritoneal infection. This is reflected in the similar serum levels attained in the two types of patients, which are shown in Figures 1-5. Significant serum levels of the five antibiotics were reached after 12 hours of dialysis; polymyxin gave the lowest level of $2 \cdot 6 \mu \mathrm{g} . / \mathrm{ml}$., while the highest level of $11 \cdot 5 \mu \mathrm{g} . / \mathrm{ml}$. was attained with cephaloridine. The relative efficiency with which each antibiotic reaches its 12-hour serum level, in terms of antibiotic administered, is expressed by the 12-hour serum level expressed as a percentage of the dialysis inflow level. This value will vary with the rates of absorption and excretion of the antibiotic; thus cloxacillin only reaches $7.5 \%$ on account of its short serum half-life of $2.5 \mathrm{hr}$., while kanamycin's serum level is $27 \%$ of the dialysis

inflow level, because of the drug's long serum halflife of 35.5 hours which more than compensates for its slower rate of absorption. A high absorption rate, combined with a fairly long serum half-life, accounts for the relatively high level of $24 \%$ given by cephaloridine.

The renal excretion of all five antibiotics was very low in these patients with renal failure. During the 24 hours following the administration of the antibiotic the amount of active drug appearing in the urine never exceeded $6 \%$ of that absorbed from the peritoneum. The maximum urine antibiotic concentrations were also very low; the highest levels of just under $20 \mu \mathrm{g}$. $/ \mathrm{ml}$. were given by kanamycin and cephaloridine, the levels for ampicillin and cloxa- 
cillin were almost always below $10 \mu \mathrm{g}$. $/ \mathrm{ml}$., while polymyxin failed to reach the lowest detectable levels of $0.5 \mu \mathrm{g} . / \mathrm{ml}$.

Figures 1-5 show the antibiotic concentrations in the serum during and after dialysis. Cloxacillin differs from the other four antibiotics in that the rise in concentration soon tails off instead of continuing throughout the period of dialysis. The time required for cloxacillin to reach half the 12-hour serum level is thus only 1.5 hours as compared with 4.5-5.2 hours taken by the other antibiotics. This is probably a reflection of its high rate of clearance from the serum.

\section{DISCUSSION}

The results show that when cloxacillin, ampicillin, cephaloridine, kanamycin, and polymyxin are administered in dialysis fluid to patients with end stage renal failure, therapeutic serum levels are achieved. Similar results were obtained by Bulger, Lindholm, Murray, and Kirby (1964) using cephalothin, ampicillin, tetracycline, and chloramphenicol, and by Ruedy (1966), using tetracycline and ampicillin.

The administration of antibiotics in the dialysis fluid is probably the best way of treating peritoneal infections as bacteria free in the peritoneal cavity are exposed to high levels of antibiotic, while those in the subserosal tissues will be exposed to levels at least as high as those shown to be reached in the serum. If the antibiotics are given by another route, especially if antibiotic-free dialysis fluid is also being administered, the levels attained in the tissues surrounding the peritoneum and in the peritoneal cavity itself will be lower than the blood levels. This difference is important when potentially toxic antibiotics like polymyxin or kanamycin are being used, as in these instances blood levels must be kept fairly low.

The five antibiotics studied, when given in the recorded concentrations, did not produce any local peritoneal discomfort and saved the patients from having extra tablets or injections. As antibiotics given in this way reach therapeutic serum levels there is probably a place for this form of administration when treating the milder extraperitoneal infections in this group of patients. An additional advantage is that excessive blood levels of toxic 음 antibiotics can easily be avoided because in the absence of active peritoneal transport the blood level $\stackrel{?}{?}$ will always remain below the dialysis inflow level믐 of the antibiotic. Thus in the one patient who received a course of kanamycin at a concentration of $20 \mu \mathrm{g} . / \mathrm{ml}$. in the inflow fluid the blood level $\stackrel{\varnothing}{\varnothing}$ stabilized around $10 \mu \mathrm{g} . / \mathrm{ml}$. after having reached $7 \mu \mathrm{g} . / \mathrm{ml}$. after the first dialysis period.

Kunin and Finland (1959) have shown that most. antibiotics have much longer serum half-lives in $\vec{\omega}$ patients with renal failure than in normal people and the half-lives of ampicillin, cephaloridine, kanamycin, and polymyxin found in this study were iv sufficiently long for the serum levels of the antibiotics to be well maintained between dialysis periods. Cloxacillin differs from the other four $\infty$ antibiotics studied in having a short half-life even in the presence of renal failure and it thus resembles $\vec{C}$ the other isoxazole penicillin, oxacillin (Bulger, Lindholm, Murray, and Kirby 1964). It would appear desirable to give a supplementary dose of 2 cloxacillin between dialysis periods in order to main- $\vec{\varphi}$ tain the serum level.

The observed maximum urine concentrations of all the drugs were very low but the highest were obtained with kanamycin and cephaloridine. Thus of the five antibiotics tested, these two would probably be the most useful in treating urinary infections in end stage chronic renal failure.

\section{REFERENCES}

Bulger, R. J., Bennett, J. V., and Boen, S. T. (1965). J. Amer. med. Ass., 194, 1198.

, Lindholm, D. D., Murray, J. S., and Kirby, W. M. M. (1964) Ibid., 187, 319.

Cohn, I., Jr. (1962). Int. Abstr. Surg., 114, 309.

-_, and Cotlar, A. M. (1962). Ann. Surg., 155, 532.

Greenberg, P. A and Sanford, J. P. (1967). Ann. intern. Med. 66, 465 Grove, D. C., and Randall, W. A. (1955). Assay Methods of Antibiotics. A Laboratory Manual. Medical Encyclopedia, New York.

Kunin, C. M., and Finland, M. (1959). Arch. intern. Med., 104, 1030.?

Maxwell, M. H., Rockney, R. E., Kleeman, C. R., and Twiss, M. R.O (1959). J. Amer. med. Ass., 170, 917.

Mowbray, J. F., Cohen, S. L., Doak, P. B., Kenyon, J. R., Owen, K., I Percival, A., Porter, K. A., and Peart, W. S. (1965). Brit.O med. J., 2, 1387. Palmer, R. A., Newell, J. E., Gray, E. J., and Quinton, W. E. (1966). N
New Engl. J. Med., 274, 248.

Rose, H. D., Roth, D. A., and Koch, M. L. (1965). Amer. J. med. Sci., N $250,66$.

Ruedy, J. (1966). Canad. med. Ass. J., 94, 257.

Thomson, W. B., Buchanan, A. A., Doak, P. B., and Peart, w. S. $\omega$ (1964). Brit. med. J., 1, 932. 